Article

\title{
Evaluation of the Ridaquick Rotavirus/Adenovirus Immuno-Chromatographic Assay in Real-Life Situation
}

\author{
Francis Simo-Fouda ${ }^{1}\left(\mathbb{D}\right.$, Laetitia Ninove ${ }^{1}$, Léa Luciani ${ }^{1}$, Christine Zandotti ${ }^{1}$, Céline Gazin ${ }^{2}$, Remi N. Charrel ${ }^{1}$ (D) \\ and Antoine Nougairède ${ }^{1, *}$ \\ 1 Unité des Virus Emergents (UVE: Aix Marseille Univ, IRD 190, INSERM 1207, IHU Méditerranée Infection), \\ 13005 Marseille, France; francis-girauld.simo-fouda@etu.univ-amu.fr (F.S.-F.); \\ laetitia.ninove@univ-amu.fr (L.N.); lea.luciani@ap-hm.fr (L.L.); christine.zandotti@ap-hm.fr (C.Z.); \\ remi.charrel@univ-amu.fr (R.N.C.) \\ 2 Institut Hospitalo-Universitaire (IHU) Méditerranée Infection, 13005 Marseille, France; celine.gazin@ap-hm.fr \\ * Correspondence: antoine.nougairede@univ-amu.fr
}

check for updates

Citation: Simo-Fouda, F.; Ninove, L.; Luciani, L.; Zandotti, C.; Gazin, C.; Charrel, R.N.; Nougairède, A

Evaluation of the Ridaquick

Rotavirus/Adenovirus

Immuno-Chromatographic Assay in Real-Life Situation. Pathogens 2021, 10, 1213. https://doi.org/10.3390/ pathogens10091213

Academic Editor: Carl Kirkwood

Received: 28 June 2021

Accepted: 15 September 2021

Published: 18 September 2021

Publisher's Note: MDPI stays neutral with regard to jurisdictional claims in published maps and institutional affiliations.

Copyright: (c) 2021 by the authors. Licensee MDPI, Basel, Switzerland. This article is an open access article distributed under the terms and conditions of the Creative Commons Attribution (CC BY) license (https:// creativecommons.org/licenses/by/ $4.0 /)$.

\begin{abstract}
Immunochromatographic tests (ICT) are diagnostics tools providing rapid results without the need for specialized equipment. Our aim was to evaluate retrospectively the rotavirus and adenovirus ICT routinely used in the virology laboratory serving the University Hospital of Marseille, France. From January 2017 to March 2020, 715 stool specimens from patients were screened using the Ridaquick Rotavirus/Adenovirus Combi ICT (RR/AC ICT) and a commercially available multiplex PCR detection kit. Rotavirus was detected in $9.2 \%$ of specimens by PCR and $7.7 \%$ of specimens by RR/AC ICT while adenovirus was detected in $8.5 \%$ of specimens by PCR and $2.4 \%$ of specimens by RR/AC ICT. The RR/AC ICT parameters for rotavirus were 75.8\% sensitivity, $99.2 \%$ specificity, 90.9\% positive predictive value (PPV) and 97.6\% negative predictive value (NPV). The RR/AC ICT parameters for adenovirus were $6.6 \%$ sensitivity, $98.0 \%$ specificity, $23.5 \%$ PPV and $91.8 \%$ NPV. While the ICT test may be suitable for rotavirus detection, a PCR-based assay is better adapted for adenovirus detection in stools.
\end{abstract}

Keywords: rotavirus; adenovirus; immunochrommatographic test; ICT; PCR

\section{Introduction}

Diarrhea remains a frequent illness throughout the world and despite extensive use of diagnostic tools, the cause of many episodes often remains unresolved [1,2]. Studies on acute gastroenteritis recognized rotaviruses and noroviruses as the leading causes, followed by adenoviruses, sapoviruses and human astroviruses [3-5].

Several point-of-care immunochromatographic tests (ICT) for viral enteropathogens are commercially available [6]. ICT are attractive because each sample can be tested individually with results available in $<30 \mathrm{~min}$; moreover, they require neither specific equipment nor advanced personnel training $[7,8]$. However, ICT often suffer from low sensitivity, failing to produce a positive result when the viral loads of rotavirus and adenovirus are low [7]. In contrast, molecular detection of viral targets using PCR result in higher assay sensitivity and specificity, making them the 'gold standard' for the detection of viral enteric pathogens $[9,10]$. Few studies have evaluated the performances of the Ridaquick Rotavirus/Adenovirus Combi ICT (RR/AC ICT) $[6,11,12]$. The aim of the study was to retrospectively assess the sensitivity and specificity of the RR/AC ICT routinely used in point of care settings in comparison with the Fast Track Diagnostics (FTD) Viral Gastroenteritis assay (FTD-GA; Fast Track Diagnostics, Luxembourg), which is a commercial multiplex PCR assay. 


\section{Results}

A total of 13,280 samples were received in the laboratory for detection of enteric viruses during the study period. Amongst these samples, 715 samples from 659 patients were tested using both assays and were included in this study. The median age was 2 years (range 1 day-98 years) with a female/male ratio of 1.0/1.1.

Of the 715 specimens, $7.7 \%$ (55/715) were positive for rotavirus using ICT and $9.2 \%$ $(66 / 715)$ were positive using PCR (Table 1). Adenovirus was detected in $2.4 \%(17 / 715)$ of specimens using ICT and 8.5\% (61/715) of specimens using PCR (Table 1). Using FTDGA PCR assay as reference, there were more false positive than true positive detection for adenovirus.

Table 1. Comparative detection of rotavirus and adenovirus in stools.

\begin{tabular}{cccccc}
\hline & \multicolumn{2}{c}{ Rotavirus } & \multicolumn{3}{c}{ Adenovirus } \\
\hline ICT & PCR & No. of Specimens & ICT & PCR & No. of Specimens \\
\hline Positive & Positive & 50 & Positive & Positive & 4 \\
Positive & Negative & 5 & Positive & Negative & 13 \\
Negative & Positive & 16 & Negative & Positive & 57 \\
Negative & Negative & 644 & Negative & Negative & 641 \\
\multicolumn{2}{c}{ Total } & 715 & \multicolumn{2}{c}{ Total } & 715 \\
\hline
\end{tabular}

Using FTD-GA PCR assay as reference, the performance of the ICT for detection of rotavirus and adenovirus in stool specimens are presented in Table 2. Overall, our results indicated acceptable performances for rotavirus detection; concordance between ICT and PCR was 97.1\% (95\% confidence interval: 95.8-98.3\%). In contrast, the ICT performance for adenovirus detection was poor with low sensitivity $(6.6 \%)$ and positive predictive value (PPV; $23.5 \%$ ) although the result concordance between the assays was $90.2 \%$ (95\% confidence interval: $88.0-92.4 \%$ ). It is worth noticing that the FTD-GA PCR assay covers all genotypes of Human mastadenovirus A to G species [13].

Table 2. Performances of RR/AC ICT.

\begin{tabular}{ccccc}
\hline & Sensitivity (\%) & Specificity (\%) & PPV (\%) & NP (\%) \\
\hline Rotavirus ICT & 75.8 & 99.2 & 90.9 & 97.6 \\
\hline Adenovirus ICT & 6.6 & 98.0 & 23.5 & 91.8
\end{tabular}

FTD-GA PCR assay was used as reference method. PPV = Positive predictive value, NPV = Negative predictive value.

Available cycle threshold values $(\mathrm{Ct})$ of positive samples are shown in Table 3 (278/715 samples tested during corresponding period). For rotavirus, almost all samples tested positive (16/19) using the FTD-GA PCR assay were also positive with the ICT, with Ct values ranging from 15 to 25 . In contrast, for adenovirus, only one sample with a $\mathrm{Ct}$ value of 12 was positive with both FTD-GA PCR assay and ICT. All the other PCR positive samples were ICT negative with $\mathrm{Ct}$ values ranging from 18 to 34 .

Table 3. Available data on positive samples (August 2018-March 2020).

\begin{tabular}{|c|c|c|c|c|c|c|c|c|c|c|c|}
\hline \multicolumn{6}{|c|}{ Rotavirus } & \multicolumn{6}{|c|}{ Adenovirus } \\
\hline N. & $\operatorname{Sex}^{+}$ & $\begin{array}{c}\text { Age } \\
\text { (Years) }\end{array}$ & $\begin{array}{l}\text { Sampling } \\
\text { Month }\end{array}$ & $\operatorname{PCR}(\mathrm{Ct})$ & ICT & N. & $\operatorname{Sex}^{+}$ & $\begin{array}{c}\text { Age } \\
\text { (Years) }\end{array}$ & $\begin{array}{l}\text { Sampling } \\
\text { Month }\end{array}$ & PCR (Ct) & ICT \\
\hline 1 & $\mathrm{~F}$ & $<1$ & January 2020 & $\underset{\ddagger}{\text { Positive (15) }}$ & Positive & 1 & M & $<1$ & February 2020 & $\underset{\ddagger}{\text { Positive (12) }}$ & Positive \\
\hline 2 & $\mathrm{~F}$ & $<1$ & March 2019 & Positive (17) & Positive & 2 & $M$ & $<1$ & May 2019 & Positive (18) & Negative \\
\hline
\end{tabular}


Table 3. Cont.

\begin{tabular}{|c|c|c|c|c|c|c|c|c|c|c|c|}
\hline \multicolumn{6}{|c|}{ Rotavirus } & \multicolumn{6}{|c|}{ Adenovirus } \\
\hline N. & Sex $^{+}$ & $\begin{array}{c}\text { Age } \\
\text { (Years) }\end{array}$ & $\begin{array}{l}\text { Sampling } \\
\text { Month }\end{array}$ & $\operatorname{PCR}(\mathrm{Ct})$ & ICT & N. & $\operatorname{Sex}^{+}$ & $\begin{array}{c}\text { Age } \\
\text { (Years) }\end{array}$ & $\begin{array}{l}\text { Sampling } \\
\text { Month }\end{array}$ & PCR $(C t)$ & ICT \\
\hline 3 & M & 7 & September 2018 & Positive (17) & Positive & 3 & $\mathrm{~F}$ & 1 & September 2019 & Positive (20) & Negative \\
\hline 4 & M & 1 & March 2020 & Positive (18) & Positive & 4 & $\mathrm{~F}$ & 1 & October 2019 & Positive (21) & Negative \\
\hline 5 & $\mathrm{~F}$ & 4 & March 2019 & Positive (18) & Positive & 5 & $\mathrm{~F}$ & $<1$ & February 2020 & Positive (23) & Negative \\
\hline 6 & M & $<1$ & September 2018 & Positive (18) & Positive & 6 & F & 92 & January 2020 & Positive (23) & Negative \\
\hline 7 & M & $<1$ & April 2019 & Positive (19) & Positive & 7 & $\mathrm{~F}$ & $<1$ & October 2018 & Positive (23) & Negative \\
\hline 8 & $\mathrm{~F}$ & $<1$ & October 2018 & Positive (19) & Positive & 8 & M & $<1$ & October 2019 & Positive (27) & Negative \\
\hline 9 & M & 1 & March 2019 & Positive (21) & Positive & 9 & M & 6 & September 2019 & Positive (27) & Negative \\
\hline 10 & M & 4 & March 2020 & Positive (22) & Negative & 10 & M & 3 & November 2019 & Positive (31) & Negative \\
\hline 11 & $\mathrm{~F}$ & 2 & April 2019 & Positive (22) & Positive & 11 & M & 2 & February 2020 & Positive (32) & Negative \\
\hline 12 & M & $<1$ & March 2019 & Positive (22) & Positive & 12 & M & 1 & March 2020 & Positive (32) & Negative \\
\hline 13 & $\mathrm{~F}$ & 1 & March 2020 & Positive (23) & Positive & 13 & M & 2 & January 2020 & Positive (33) & Negative \\
\hline 14 & M & $<1$ & March 2019 & Positive (23) & Negative & 14 & $\mathrm{~F}$ & 4 & March 2019 & Positive (33) & Negative \\
\hline 15 & F & $<1$ & March 2019 & Positive (23) & Positive & 15 & M & 1 & October 2019 & Positive (33) & Negative \\
\hline 16 & M & $<1$ & February 2019 & Positive (23) & Positive & 16 & M & 4 & March 2020 & Positive (34) & Negative \\
\hline 17 & M & 1 & December 2019 & Positive (25) & Positive & 17 & M & 50 & May 2019 & Negative & Positive \\
\hline 18 & M & 1 & May 2019 & Positive (25) & Positive & 18 & M & $<1$ & June 2019 & Negative & Positive \\
\hline 19 & $\mathrm{~F}$ & 2 & March 2019 & Positive (26) & Negative & 19 & F & 23 & August 2019 & Negative & Positive \\
\hline 20 & M & 35 & March 2019 & Negative & Positive & 20 & M & 1 & October 2019 & Negative & Positive \\
\hline 21 & M & 13 & August 2019 & Negative & Positive & & & & & & \\
\hline 22 & F & 79 & September 2019 & Negative & Positive & & & & & & \\
\hline 23 & M & $<1$ & October 2019 & Negative & Positive & & & & & & \\
\hline
\end{tabular}

\section{Discussion}

The FTD-GA PCR detected more rotavirus and adenovirus cases than the ICT although this was not unexpected. The ICT manufacturer reported rotavirus assay parameters at 97.8\% sensitivity, 94.4\% specificity, 93.8\% PPV and 98.1\% NPV [14]. In other studies performed in Ghana, Turkey and Italy that evaluated also the same RR/AC ICT, sensitivity for rotavirus ranged from $75 \%$ to $89 \%$ whereas specificity ranged from $72 \%$ to $100 \%[6,11,12]$. Our results are in line with previous studies and confirm that this RR/AC ICT is valuable for rapid detection of rotaviruses [6,11,12].

For adenovirus, the manufacturer reported performance of $72.7 \%$ sensitivity, $98.2 \%$ specificity, 97.0\% PPV and 80.9\% NPV [14]. Sensitivity and PPV were much higher than those observed in our study ( $6.6 \%$ sensitivity and $23.5 \%$ PPV). In our study, the observed lack of sensitivity cannot be due to sampling and processing procedure since the samples were processed/stored within $4 \mathrm{~h}$ after collection. Moreover, our results are in the same order of magnitude with those previously reported with sensitivity ranging from $22.0 \%$ to $28.6 \%[6,12]$.

The highly discrepant performances claimed by the manufacturer raises the question of how was constituted its panel of clinical specimens.

The reason could reside in the failure to detect specific genotypes within human adenoviruses. Even though FTD-GA PCR covers all genotypes [13], the RR/AC ICT manufacturer did not provide details about possible restrictions in genotype detection. However, FTD-GA PCR may detect adenovirus genotypes that are bystanders and are not truly responsible for gastroenteritis. Interestingly, Banerjee A. et al. showed that another ICT test (VIKIA1 Rota-Adeno assay, Biomerieux, Craponne, France) that detects almost exclusively ( $98 \%$ of PCR-confirmed positive) enteric adenoviruses (genotype $40 / 41$ ) missed $35.3 \%$ of adenovirus infection due to restricted target scope $[15,16]$. In addition, previous studies have showed a high frequency of non-enteric adenovirus in stools of patients admitted for acute gastroenteritis $[17,18]$. Other Rotavirus/Adenovirus ICT displayed sensitivities 
for enteric adenoviruses ranging from $71 \%$ to $85 \%[19,20]$. However, when including nonenteric adenoviruses, their sensitivity dropped to a great extent $[8,12,20,21]$. The very low sensitivity observed is likely to result in the inability of ICT to detect adenovirus antigens in stool samples presenting with low viral loads as described [7]

In this context, several studies concluded that they are not suitable for the routine diagnosis of adenovirus in stools and first-line tests should be PCR assays. Our results support the same conclusions for the tested RR/AC ICT.

In conclusion, this study suggests that RR/AC ICT can be used as a point-of-care test for rotavirus detection, and that the observed result can be considered as definitive in the vast majority of cases, i.e., for patients without specific co-morbidities. In contrast, RR/AC ICT might not be well-suited as a first-line rapid screen for adenovirus in stools that can be successfully achieved by using a PCR-based assay for diagnosis.

\section{Materials and Methods}

\subsection{Study Design}

We performed a retrospective analysis of results from stool samples processed by trained laboratory professionals from the University Hospitals of Marseille, France. Samples were analysed from 1 January 2017 to 15 March 2020. Stool samples were collected and processed within $4 \mathrm{~h}$ after collection (24/7 activity for point-of-care laboratories). The inclusion criteria consisted of (i) any stool sample collected from an admitted or a hospitalized patient (ii) that was addressed to the point-of-care laboratory for detection of adenovirus or rotavirus, and (iii) that was subsequently transferred to the core laboratory for PCR detection or confirmation (see below). Performance of the Ridaquick Rotavirus/Adenovirus Combi ICT (R-Biopharm AG, Darmstadt, Germany) was compared to the Fast Track Diagnostics (FTD) Viral Gastroenteritis assay (FTD-GA; Fast Track Diagnostics, Luxembourg). $\mathrm{Ct}$ (cycle threshold) values provided by FTD-GA PCR could be retrieved from the laboratory files only for recent years (from 1 August 2018 to 15 March 2020 in our case).

\subsection{Immunochromatographic Test}

RR/AC ICT is a lateral-flow ICT, which uses labeled monoclonal antibodies against surface antigens of rotavirus and adenovirus. The standard operating procedure has been written according to the manufacturer's instructions. One fresh aliquot of stools was tested using the RR/AC ICT.

\subsection{Nucleic Acids Extraction}

A $100 \mathrm{mg}$ stool sample was diluted and mixed into $1 \mathrm{ml}$ sterile water; $190 \mu \mathrm{L}$ of this suspension was transferred into a $2 \mathrm{ml}$ tube that contained $2 \mu \mathrm{L}$ of FTD-GA PCR internal control, $10 \mu \mathrm{L}$ of MS2/T4 bacteriophages (in-house internal controls [22]) and $200 \mu \mathrm{L}$ of ATL buffer. This preparation was used for nucleic acid extraction with the automated extractor EZ1 ${ }^{\circledR}$ Advanced XL (Qiagen, Hilden, Germany) using EZ1 Virus Mini Kit v2.0 (Qiagen) following the manufacturer's instructions with the elution volume set at $120 \mu \mathrm{L}$.

\subsection{Rotavirus and Adenovirus PCR Detection}

Rotavirus and adenovirus FTD PCRs were performed using FTD Viral Gastroenteritis assay (ref\# FTD-3-32/64, Fast Track Diagnostics, Luxembourg). For a single reaction mix, PPMix volume was $0.75 \mu \mathrm{L}$; buffer $6.25 \mu \mathrm{L}$; enzyme $0.50 \mu \mathrm{L}$; samples $5 \mu \mathrm{L}$; plate were run on Roche LightCycler 480 real-time PCR (LC480). Cycling temperature was set to $15 \mathrm{~min}$ at $42{ }^{\circ} \mathrm{C}, 3 \mathrm{~min}$ at $94{ }^{\circ} \mathrm{C}, 40$ cycles of $8 \mathrm{~s}$ at $94^{\circ} \mathrm{C}, 34 \mathrm{~s}$ at $60^{\circ} \mathrm{C}$. Amplification curves were analyzed using Lightcycler ${ }^{\circledR} 480$ software version 1.5 .1 with standardized procedure.

\subsection{Statistics}

SPSS statistical package release 17.0 (SPSS Inc., Chicago, IL, USA) was used for data/statistical analysis. 
Author Contributions: Conceptualization, R.N.C. and A.N.; methodology, L.N., L.L., C.Z. and F.S.-F.; validation, L.N., L.L., C.Z. and C.G.; investigation, F.S.-F.; resources, C.G.; data curation, F.S.-F.; writing—original draft preparation, F.S.-F.; writing—review and editing, R.N.C. and A.N.; supervision, R.N.C. and A.N.; All authors have read and agreed to the published version of the manuscript.

Funding: FSF received a scholarship from the Fondation Méditerranée Infection. This work was supported by Aix-Marseille University.

Institutional Review Board Statement: Ethical approval was waived since all diagnostic procedures were performed following physician's prescriptions and all data were anonymized.

Informed Consent Statement: Patient consent was waived since all diagnostic procedures were performed following physician's prescriptions and all data were anonymized.

Data Availability Statement: All data are provided in the article.

Conflicts of Interest: The authors declare no conflict of interest. The funders had no role in the design of the study; in the collection, analyses or interpretation of data; in the writing of the manuscript or in the decision to publish the results.

\section{References}

1. Ayouni, S.; Estienney, M.; Hammami, S.; Neji Guediche, M.; Pothier, P.; Aouni, M.; Belliot, G.; de Rougemont, A. Cosavirus, Salivirus and Bufavirus in Diarrheal Tunisian Infants. PLoS ONE 2016, 11, e0162255. [CrossRef] [PubMed]

2. Smits, S.L.; Schapendonk, C.M.; van Beek, J.; Vennema, H.; Schurch, A.C.; Schipper, D.; Bodewes, R.; Haagmans, B.L.; Osterhaus, A.D.; Koopmans, M.P. New viruses in idiopathic human diarrhea cases, the Netherlands. Emerg. Infect. Dis. 2014, 20, 1218-1222. [CrossRef] [PubMed]

3. Desselberger, U. Viral gastroenteritis. Medicine 2017, 45, 690-694. [CrossRef]

4. Sattar, S.B.A.; Singh, S. Bacterial Gastroenteritis. In StatPearls; StatPearls Publishing: Treasure Island, FL, USA, 2020.

5. Portal, T.M.; Reymao, T.K.A.; Quindere Neto, G.A.; Fiuza, M.; Teixeira, D.M.; Lima, I.C.G.; Sousa Junior, E.C.; Bandeira, R.D.S.; De Deus, D.R.; Justino, M.C.A.; et al. Detection and genotyping of enteric viruses in hospitalized children with acute gastroenteritis in Belem, Brazil: Occurrence of adenovirus viremia by species F, types 40/41. J. Med. Virol. 2019, 91, 378-384. [CrossRef] [PubMed]

6. Weitzel, T.; Reither, K.; Mockenhaupt, F.P.; Stark, K.; Ignatius, R.; Saad, E.; Seidu-Korkor, A.; Bienzle, U.; Schreier, E. Field evaluation of a rota- and adenovirus immunochromatographic assay using stool samples from children with acute diarrhea in Ghana. J. Clin. Microbiol. 2007, 45, 2695-2697. [CrossRef] [PubMed]

7. Jiang, N.; Shi, L.; Lin, J.; Zhang, L.; Peng, Y.; Sheng, H.; Wu, P.; Pan, Q. Comparison of two different combined test strips with fluorescent microspheres or colored microspheres as tracers for rotavirus and adenovirus detection. Virol. J. 2018, 15, 44. [CrossRef] [PubMed]

8. Kim, J.; Kim, H.S.; Kim, H.S.; Kim, J.S.; Song, W.; Lee, K.M.; Lee, S.; Park, K.U.; Lee, W.; Hong, Y.J. Evaluation of an immunochromatographic assay for the rapid and simultaneous detection of rotavirus and adenovirus in stool samples. Ann. Lab. Med. 2014, 34, 216-222. [CrossRef] [PubMed]

9. Bloomfield, M.G.; Balm, M.N.; Blackmore, T.K. Molecular testing for viral and bacterial enteric pathogens: Gold standard for viruses, but don't let culture go just yet? Pathology 2015, 47, 227-233. [CrossRef] [PubMed]

10. Moutelikova, R.; Dvorakova Heroldova, M.; Hola, V.; Sauer, P.; Prodelalova, J. Human rotavirus A detection: Comparison of enzymatic immunoassay and rapid chromatographic test with two quantitative RT-PCR assays. Epidemiol. Mikrobiol. Imunol. 2019, 67, 110-113.

11. Artiran, S.; Atalay, A.; Gokahmetoglu, S.; Ozturk, M.A.; Balci, N.; Cakir, N.; Kilic, H.; Durmaz, R. Investigation of Rotavirus with Various Methods in Children with Acute Gastroenteritis and Determination of Its Molecular Epidemiology in Kayseri Province, Turkey. J. Clin. Lab. Anal. 2017, 31, e22030. [CrossRef]

12. Rovida, F.; Campanini, G.; Sarasini, A.; Adzasehoun, K.M.; Piralla, A.; Baldanti, F. Comparison of immunologic and molecular assays for the diagnosis of gastrointestinal viral infections. Diagn. Microbiol. Infect. Dis. 2013, 75, 110-111. [CrossRef] [PubMed]

13. Sciandra, I.; Piccioni, L.; Coltella, L.; Ranno, S.; Giannelli, G.; Falasca, F.; Antonelli, G.; Concato, C.; Turriziani, O. Comparative analysis of 2 commercial molecular tests for the detection of gastroenteric viruses on stool samples. Diagn. Microbiol. Infect. Dis. 2020, 96, 114893. [CrossRef] [PubMed]

14. R-Biopharm AG. RIDA ${ }^{\circledR}$ QUICK Rotavirus/Adenovirus Combi (Cassettes). Art. No.: N1003. Available online: https://clinical.rbiopharm.com/products/ridaquick-rotavirusadenovirus-combi-cassettes/ (accessed on 9 June 2021).

15. Banerjee, A.; De, P.; Manna, B.; Chawla-Sarkar, M. Molecular characterization of enteric adenovirus genotypes 40 and 41 identified in children with acute gastroenteritis in Kolkata, India during 2013-2014. J. Med. Virol. 2017, 89, 606-614. [CrossRef] [PubMed]

16. Verma, H.; Chitambar, S.D.; Varanasi, G. Identification and characterization of enteric adenoviruses in infants and children hospitalized for acute gastroenteritis. J. Med. Virol. 2009, 81, 60-64. [CrossRef] [PubMed] 
17. Wu, B.S.; Huang, Z.M.; Weng, Y.W.; Chen, F.Q.; Zhang, Y.L.; Lin, W.D.; Yu, T.T. Prevalence and Genotypes of Rotavirus A and Human Adenovirus among Hospitalized Children with Acute Gastroenteritis in Fujian, China, 2009-2017. Biomed. Environ. Sci. 2019, 32, 210-214. [CrossRef] [PubMed]

18. Gelaw, A.; Pietsch, C.; Liebert, U.G. Genetic diversity of human adenovirus and human astrovirus in children with acute gastroenteritis in Northwest Ethiopia. Arch. Virol. 2019, 164, 2985-2993. [CrossRef]

19. Gonzalez-Serrano, L.; Munoz-Algarra, M.; Gonzalez-Sanz, R.; Portero-Azorin, M.F.; Amaro, M.J.; Higueras, P.; Cabrerizo, M. Viral gastroenteritis in hospitalized patients: Evaluation of immunochromatographic methods for rapid detection in stool samples. $J$. Clin. Virol. 2020, 128, 104420. [CrossRef]

20. Kaplon, J.; Thery, L.; Bidalot, M.; Grangier, N.; Frappier, J.; Aho Glele, L.S.; de Rougemont, A.; Ambert-Balay, K. Diagnostic Accuracy of Four Commercial Triplex Immunochromatographic Tests for Rapid Detection of Rotavirus, Adenovirus, and Norovirus in Human Stool Samples. J. Clin. Microbiol. 2020, 59, e01749-20. [CrossRef] [PubMed]

21. Kas, M.P.; Maure, T.; Soli, K.W.; Umezaki, M.; Morita, A.; Bebes, S.; Jonduo, M.H.; Larkins, J.A.; Luang-Suarkia, D.; Siba, P.M.; et al. Evaluation of a rapid immunochromatographic assay for the detection of rotavirus, norovirus and adenovirus from children hospitalized with acute watery diarrhea. Papua N. Guin. Med. J. 2013, 56, 141-144.

22. Ninove, L.; Nougairede, A.; Gazin, C.; Thirion, L.; Delogu, I.; Zandotti, C.; Charrel, R.N.; De Lamballerie, X. RNA and DNA bacteriophages as molecular diagnosis controls in clinical virology: A comprehensive study of more than 45,000 routine PCR tests. PLoS ONE 2011, 6, e16142. [CrossRef] [PubMed] 